ks. Janusz Królikowski

Uniwersytet Papieski Jana Pawła II w Krakowie

DOI: $10.15290 /$ std.2016.02.02

\title{
TRYNITARNO-CHRYSTOLOGICZNE PERSPEKTYWY TEOLOGII MAŁŻEŃSTWA
}

\section{THE TRINITARIAN AND CHRISTOLOGICAL PERSPECTIVES OF THE THEOLOGY OF MARRIAGE}

Although the relation between the mystery of the Holy Trinity and the sacrament of marriage was always treated as a minor issue, it has been present in the theology for ages. It is usually situated in the context of the searching for the "traces" of the Holy Trinity in the creation. The crucial moment in the theological approach to the relation between the mystery of the Holy Trinity and marriage was the reversal of the problem in question: marriage is not only a trace of the Holy Trinity in the world - as it is in classical theology - but rather it is expected to become an active reflection of the Trinity in the relations between husband and wife, in their mutual attitudes and it is supposed to express itself in the mission undertaken and fulfilled by husband and wife especially in their uniting and simultaneously fertile love. The Holy Trinity, especially as a mystery of the everlasting and rejoicing love, for a married couple should serve as a point of reference to understand their marital identity and to shape their mutual relations which express this identity.

Trinitarian and Christological theology provide a rich material for a deepened understanding and recognition of the teaching of the former Popes who consistently emphasize the need of situating the fundamental questions regarding vocation, nature and mission of marriage in direct reference to the mystery of the Holy Trinity and the mystery of Jesus Christ. Theological perspectives unambiguously abiding by the conclusions of the theology of creation and natural law open an exceptionally broad view on marriage being the fundamental human and Christian reality, and at the same time a great mystery which 
has its origin in the highest mystery of the God in three Persons and which is fully revealed in Jesus Christ, the incarnated Son of God who died on the cross in kenotic love. Therefore it is primarily a perspective of personalism deeply rooted and directed Christologically. The mutual self-giving of husband and wife in the sacrament of marriage is a remarkable testimony given to Christ, since fidelity expressed in marital attitude reflects radicalism and greatness of love proved once and for all on the Christ's cross. The fertility of physical union of man and wife reflects not only the immeasurable fertility of Christ's death for mankind, but also the infinite fertility of Trinitarian communion which pours out on every created reality and becomes its original point of reference.

Key words: Holy Trinity, Jesus Christ, cross, love, marriage, fertility.

„Miłość jest na mocy definicji słowem, którym się posługujemy, chcąc określić sily przyciągania o charakterze osobowym".

Pierre Teilhard de Chardin ${ }^{1}$

Związek zachodzący między tajemnicą Trójcy Świętej i rzeczywistością małżeństwa ma długie dzieje $\mathrm{w}$ teologii, chociaż zawsze był ujmowany w sposób bardzo dyskretny i niejako pomocniczy. Sytuuje się on najczęściej w ramach poszukiwania „śladów” Trójcy Świętej w stworzeniu. Początków tego związku można szukać już u Ojców Kościoła w kontekście podejmowanych przez nich różnych zagadnień trynitarnych ${ }^{2}$. W kolejnych wiekach, zwłaszcza teologia trynitarna, podtrzymywała to przekonanie, chociaż nie nadawała mu jakiegoś większego znaczenia ${ }^{3}$. Pewne zintensyfikowanie refleksji teologicznej na ten temat, zwłaszcza w odniesieniu do problematyki chrystologicznej, znajdujemy w XIX wieku u Matthiasa J. Scheebena, który otworzył nowe perspektywy w ramach teologii małżeństwa, podobnie zresztą jak w odniesieniu do wielu innych zagadnień teologicznych ${ }^{4}$.

Decydującym momentem $w$ teologicznym spojrzeniu na relacje zachodzące między tajemnicą Trójcy Świętej i małżeństwem, było odwrócenie stawianego problemu: małzeństwo nie tyle jest śladem Trójcy Świętej w świecie - jak

$1 \quad$ P. Teilhard de Chardin, O szczęściu, cierpieniu, miłości, tł. W. Sukiennicka, M. Tazbir, Warszawa 2001, s. 94.

2 Święty Augustyn stwierdza np.: „Trinitatem imaginis Dei [...] in coniugio masculi et femine atque in eorum prole" (De Trinitate 12, 5, 5).

3 Por. L. Gendron, Le mystère de la Trinité et la symbolique familiale, Roma 1975; B. de Margerie, La Trinité chrétienne dans l'histoire, Paris 1975, s. 367-390.

$4 \quad$ Por. M. J. Scheeben, Tajemnice chrzéśijaństwa, t1. J. Rostworowski, I. Bieda, Kraków 1970, s. 468-482; idem, Handbuch der katholischen Dogmatik, Freiburg im Br. 1933, s. 776-784. 
w teologii klasycznej - co raczej ma ono stawać się czynnym odzwierciedleniem Trójcy w relacjach zachodzących między mężem i żoną, w ich wzajemnych postawach oraz ma wyrażać się w misji podjętej i pełnionej przez małżonków, szczególnie w jednoczącej ich i równocześnie płodnej miłości. Trójca Święta, zwłaszcza jako tajemnica wiecznej i uszczęśliwiającej miłości, ma być dla małżonków punktem odniesienia dla zrozumienia swojej tożsamości małżeńskiej oraz dla kształtowania wzajemnych relacji, które tę tożsamość wyrażają. Początków takiego spojrzenia można dopatrywać się w niektórych wypowiedziach na temat małżeństwa, które znajdujemy w nauczaniu papieża Piusa XII. Zostały one przyjęte w nauczaniu II Soboru Watykańskiego, który nauczając w konstytucji Gaudium et spes na temat człowieka jako stworzonego na obraz Boży, zwraca uwagę, że jego odzwierciedlenia należy także upatrywać w dwoistości płciowej człowieka jako mężczyzny i kobiety (nr 12). Nauczanie na ten temat zostało potem rozwinięte przez papieża Pawła VI. W nauczaniu Papieża Jana Pawła II znajdujemy wyjątkowo częste powracanie do tego zagadnienia, a jego spójne rozwinięcie zawierają zwłaszcza adhortacja Familiaris consortio o małżeństwie i rodzinie (22 listopada 1981 r.) oraz List do rodzin z okazji Roku Rodziny (2 lutego 1994 r.). W tym ostatnim dokumencie czytamy ważkie stwierdzenia: „W świetle Nowego Testamentu widać wyraźnie, że odniesienia dla tej wspólnoty [tzn. małżeństwa i rodziny], jej prawzoru, należy szukać w Bogu samym. Zawiera się on w trynitarnej tajemnicy Jego Życia. Boskie «My» jest przedwiecznym prawzorem dla ludzkiego «my» - tego przede wszystkim, jakie mają stanowić mężczyzna i kobieta stworzeni na obraz i podobieństwo Boga samego" (nr 6) ${ }^{5}$. Istotne elementy nauczania Papieża Jana Pawła II dotyczące trynitarnego ujmowania rzeczywistości małżeństwa zostały przywołane w adhortacji papieża Franciszka Amoris laetitia (nr 121).

W tym miejscu proponujemy syntetyczne zwrócenie uwagi na niektóre zagadnienia trynitarne i chrystologiczne, które pozwalają pogłębić teologię małżeństwa, a zarazem otwierają kluczowe perspektywy na wzniosłe traktowanie rzeczywistości małżeńskiej i na podjęcie takiej odpowiedzialności w tej dziedzinie, która odpowiada tej wzniosłości. Jest to tym bardziej konieczne, że teologia dogmatyczna często nie nadąża za wyzwaniami, które rodzą się z uważnej lektury nauczania dawanego w odniesieniu do tego pilnego zagadnienia przez ostatnich papieży. Zbyt często zagadnienie małżeństwa jest zostawione tylko teologii moralnej i prawu kanonicznemu. Być może wiele zbędnych dyskusji, które pojawiły się przy okazji obrad ostatniego Synodu Biskupów poświęconego

Warto zwrócić uwagę, że w dokumencie tym Papież Jan Paweł II dokonał bardzo szczególnego rozwinięcia pojęcia osoby w kluczu komunijnym. Por. P. Carlotti, La famiglia comunione di persone. Alcune considerazioni sulla Lettera alle Famiglie di Giovanni Paolo II, „Salesianum” 56 (1994) s. 717-740. 
małżeństwu i rodzinie, dałoby się uniknąć, gdyby teologia dogmatyczna więcej uwagi poświęcała podstawowym zagadnieniom małżeństwa, ukazując je bardziej wyraźnie w perspektywie teologicznej, a zwłaszcza chrystologicznej6.

\section{Człowiek dialogiczny - antropologia}

Małżeństwo jest fundamentalnie rzeczywistością antropologiczną, ale aby je właściwie rozumieć i usytuować, należy sięgnąć do właściwej antropologii ${ }^{7}$ Już sam fakt, że w małżeństwie chodzi o „dwoje”, zmusza nas do zdystansowania się w stosunku do antropologii o charakterze indywidualistycznym, a zarazem wskazuje na potrzebę sięgnięcia do antropologii wypracowanej i znacznie pogłębionej w nurcie współczesnej filozofii personalistycznej, a zwłaszcza w filozofii dialogu (Buber, Ebner, Rosenzweig) ${ }^{8}$. Podstawowa teza tej antropologii mówi, że osoba ludzka otrzymuje istnienie, ponieważ Boskie „My” chce jej dla niej samej, zwraca do niej swoje zaproszenie i powołuje ją do istnienia9. Nowożytna tradycja indywidualistyczna kładzie nacisk na to, że punktem wyjścia refleksji filozoficznej jest stawianie pytań i w tej perspektywie patrzy następnie na każdą rzeczywistość antropologiczną, a tym samym każe człowiekowi najpierw w sobie szukać racji siebie oraz z siebie samego wyprowadzić rozumienie siebie i konsekwencje dotyczące urzeczywistniania odkrytego rozumienia. Takie stawianie sprawy nie gwarantuje jednak autentyczności udzielanych odpowiedzi na pojawiające się pytania, a następnie w praktyce harmonijnego i komunijnego rozszerzenia siebie ${ }^{10}$. Antropologia indywidualistyczna $z$ tych podstawowych racji nie jest wystarczająca do podjęcia zagadnienia małżeństwa i do jego adekwatnego ujęcia.

W tym miejscu nie będziemy omawiać całego wkładu, jaki wniosła współczesna filozofia personalistyczna, do głębszego rozumienia osoby, zwłaszcza w jej wymiarze komunijnym, dialogicznym i relacyjnym, a tym samym do rozumienia

$6 \quad$ Na potrzebę takiego ujmowania zagadnienia małżeństwa wskazała Międzynarodowa Komisja Teologiczna w dokumencie: Doktryna katolicka o sakramencie malżeństwa (1977), [w:] Od wiary do teologii. Dokumenty Międzynarodowej Komisji Teologicznej 1969-1996, J. Królikowski (red.), Kraków 2000, s. 89-110.

7 Por. D. von Hildebrandt, Die Ehe, München 1929.

8 Por. J. Mader, Filozofia dialogu, [w:] Teksty filozoficzne, Kraków 1985, s. 59-86.

9 W konstytucji soborowej Gaudium et spes został podkreślony ten sam aspekt, gdy stwierdza się, że człowiek jest „jedynym stworzeniem, którego Bóg chciał ze względu na nie samo” (nr 24).

10 Por. S. Grygiel, Errantes revoca! Esej o samoświadomości, Transcendencji i pojednaniu, [w:] Teksty filozoficzne, Kraków 1986, s. 142-160. 
małżeństwa ${ }^{11}$. Wystarczy zwrócić uwagę na dwa elementy, które w pewnym sensie są decydujące dla właściwego usytuowania, a potem rozwijania zagadnień dotyczących małżeństwa. Są to zagadnienia dialogu i płciowości.

Najbardziej wymownym świadectwem roli dialogu w realnym konstytuowaniu się osoby i w dochodzeniu przez nią do dojrzałości jest język. Język jest środkiem, którego jednostka nie tworzy, ale raczej go znajduje i przyjmuje, aby móc nawiązać komunikację. Aby kwestię tę widzieć bardziej jednoznacznie, należy dokonać rozróżnienia między jednostką i osobą, aby zobaczyć znaczenie osoby i sposób jej konstytuowania się. Jest znane sformułowanie, którego autorem jest Jacques Maritain, według którego jednostka istnieje dla społeczeństwa, ale społeczeństwo istnieje dla osoby ${ }^{12}$. Jednostka stanowi centrum, które tworzą intelekt i wola. Są to duchowe władze wspólne wszystkim. Osoba natomiast jest jedyna, niepowtarzalna i niezastąpiona. Wynika z tego, że „ja” nigdy nie może stać się osobą, jeśli nie otrzymuje zaproszenia od kogoś drugiego, czyli jeśli nie zostaje nawiązany dialog. Wiara odsłania najwszechstronniejsze i najwyższe implikacje tej prawdy. Tylko otrzymując zaproszenie od Boga, który nawiązuje z człowiekiem dialog, człowiek może realizować się jako osoba - osoba, która należy do siebie i do nikogo innego, ponieważ otrzymała zaproszenie od Boga w sposób całkowicie jedyny, niepowtarzalny i niezastąpiony. Papież Paweł VI wielokrotnie mówił w tym wypadku o „dialogu zbawienia”, który nawiązał Bóg z człowiekiem, aby prowadzić go potem swoimi drogami, których celem jest osiągnięcie Zbawienia w Bogu ${ }^{13}$.

Drugim elementem antropologicznym, na którego znaczenie zwróciła uwagę filozofia o charakterze personalistycznym, jest płciowość. Osoba ludzka nie istnieje jako abstrakcyjne „ja” lub „ty”, ale jest ona zawsze wcielona i urzeczywistnia się na sposób płciowy. Z tej racji płciowość, będąc przede wszystkim zjawiskiem biologicznym, sprawia jednak, że osoba ma charakter płciowy w każdym wymiarze bytu męskiego lub kobiecego. Tym, co różni mężczyznę i kobietę od zwierząt, jest właśnie fakt, że ich płciowość jest i musi być zintegrowana w ich osobie. Ich płciowość jest środkiem, aby wyrazić swoje zjednoczenie $z$ drugim. Płciowość staje się więc środkiem wyrażającym sposób samooddania drugiemu. To, co biologiczne, zostaje zintegrowane w tym, co ludzkie ${ }^{14}$.

$11 \quad$ Szerokie ujęcia w perspektywie personalistycznej teologii małżeństwa zaprezentowali: A. Scola, Il mistero nuziale. Studi sulla persona e la famiglia, t. 1-2, Milano 1998-2000; M. Ouellet, Divina somiglianza. Antropologia trinitaria della famiglia, t. 1, Roma 2004.

12 Rozwinięcie tej tezy w: J. Maritain, Pisma filozoficzne, tł. J. Fenrychowa, Kraków 1988, s. 327-345.

13 Por. Paweł VI, encyklika Ecclesiam suam, 71-77.

14 Por. J. Maritain, R. Maritain, Matrimonio, amore e amicizia. Per una spiritualità della vita coniugale, Milano 1994, s. 27-47. 
Warto tutaj zwrócić uwagę na to, że antropologia współczesna w niektórych swoich nurtach dodaje do rozumienia płciowości także jeszcze jeden wymiar, który ukazuje się, gdy zostanie ona zestawiona ze śmiercią. Każdy akt współżycia płciowego jest w gruncie rzeczy buntem przeciw śmierci. Istota ludzka, pomnażając rodzaj ludzki, buntuje się przeciw śmierci. Można w znacznym stopniu zgodzić się z tymi filozofami, którzy widzą wewnętrzny związek między aktem płciowym i śmiercią. W każdym akcie współżycia ludzkiego w pewnym sensie doświadcza się śmierci. Bardzo wymownie wskazał na ten fakt Włodzimierz Sołowjow w swojej rozprawie zatytułowanej Sens miłości, w której pisał: „Śmierć jest dezintegracją osoby, rozpadem składających się na nią faktorów. Podział na dwie płci - nie likwidowany przez zewnętrzne i przemijające zjednoczenie w akcie płciowym - podział ludzkiej osoby na element męski i element żeński jest już sam $z$ siebie stanem dezintegracji i początkiem śmierci. Trwanie w płciowym podziale oznacza trwanie na drodze śmierci, a kto nie chce lub też nie może zejść z tej drogi, powinien z naturalnej konieczności przejść ją do końca. Kto podtrzymuje korzeń śmierci, ten w nieunikniony sposób musi zakosztować jej owocu" ${ }^{15}$. Aby spójnie rozwiązać ten problem i usytuować go we właściwej perspektywie, należy odwołać się do wydarzenia Śmierci Chrystusa na krzyżu, do którego nawiążemy w dalszym ciągu naszych refleksji.

\section{Aspekty teologiczne}

Po wskazaniu na niektóre aspekty antropologiczne dotyczące człowieka w relacji do małżeństwa, zwróćmy teraz uwagę na zagadnienia ściślej teologiczne dotyczące tej samej rzeczywistości. Zastosujemy w tym miejscu, idąc zwłaszcza za strukturą wypowiedzi Papieża Jana Pawła II na temat małżeństwa, metodę, którą można nazwać „odgórną”. W świetle tego założenia pierwotny, a zarazem ostateczny fundament małżeństwa oraz doświadczenia „ja” - „ty” znajduje się w samej Trójcy Świętej. Filozofie dialogu, budowane w oparciu o wyłączne pogłębienie schematu ,ja” - „ty”, w swojej interpretacji małżeństwa narażają się na niebezpieczeństwo zamknięcia się w podwójnym monologu: kobiety w stosunku do mężczyzny i mężczyzny w stosunku do kobiety ${ }^{16}$. Już w XII wieku Ryszard z opactwa św. Wiktora wykazał, że każda autentyczna miłość między „ja” i „ty” musi obejmować pragnienie dzielenia się sobą z innym, a więc musi przelać się na „trzeciego”. Małżeństwo jako „przymierze” między mężczyzną i kobietą jest oparte na trynitarnym bycie Boga. Trójca jest doskonałą, wieczną

15 W. Sołowjow, Sens miłości, tł. H. Paprocki, Kęty 2002, s. 33.

16 Niejednokrotnie w kontekście małżeństwa słusznie mówi się, że może ono przybrać postać „egoizmu we dwoje”. Ma to miejsce zwłaszcza wtedy, gdy następuje w nim pozytywne wykluczenie potomstwa. 
i Boską komunią, jest tajemnicą uosobionej miłości. Pochodzenia w Trójcy nie są niczym niż pochodzeniami miłości. Trójca jest - można powiedzieć za Hansem Ursem von Balthasarem - dynamicznym, witalnym, dramatem miłości ${ }^{17}$. Koncepcje te chcą podkreślić, że w Bogu całe bycie polega na nieustannym i pełnym dawaniu siebie samego drugiemu.

Od wieczności Ojciec przelewa swoje bycie na Syna, a Syn od wieczności jest doskonałą odpowiedzią miłości w stosunku do Ojca. Syn jest zasadą receptywną w Trójcy - On jest Boskim przyjmowaniem; przyjmuje On w pełni miłość Ojca, aby zwracać ją Ojcu w swoim doskonałym „tak” mówionym Jego miłości. Z tej wzajemnej wymiany miłości wyłania się trzecia osoba - Duch Święty, który jest osobowym aktem miłości Ojca i Syna, jest Ich miłością osobową i Ich komunią miłości; jest osobowym „rezultatem” Ich aktu miłości. Istnienie Ducha Świętego w Trójcy ukazuje, że z życia Bożego jest wykluczony jakikolwiek akt egoizmu. Ojciec i Syn nie zatrzymują niczego dla siebie, ale w pełni osobowo oddają się sobie. Ich miłość może być więc nazwana miłością absolutnie „otwartą”. Z tej racji Duch Święty, zwłaszcza w tradycji wschodniej, jest słusznie nazywany „ekstazą” miłości Ojca i Syna. Pojęcie to chce wskazać najwyższy stopień i wyraz, jaki może przybrać miłość. Jest to miłość tak nieskończenie płodna, że z niej wypływa całe stworzenie. Pierwotnym miejscem stworzenia jest więc nieskończona przestrzeń otwarta przez miłość Ojca i Syna w Duchu Świętym ${ }^{18}$.

Ta wizja trynitarna stanowi podstawę do właściwego spojrzenia na małżeństwo i jego konkretne wyrażanie się. Chociaż małżeństwo ma naturalną podstawę w płciowości i w prokreacji potomstwa, chrześcijanie wiedzą, że jego podstawa jest znacznie głębsza. $Z$ wiecznego zamysłu Boga wynika, że mężczyzna i kobieta w pełnym, jednoczącym i płodnym samooddaniu się sobie stanowią odzwierciedlenie komunii trynitarnej. Niestety, grzech wszedł w świat z powodu pierwotnego upadku, a wraz z nim także płciowość, która była przeznaczona do tego, aby być fizycznym wyrazem daru z siebie, została naznaczona egoizmem, podziałem i dwuznacznością. Stała się miejscem „dramatycznej walki”, jak stwierdza konstytucja Gaudium et spes (nr 13). Drugi przestał być „partnerem” płodnego zjednoczenia w miłości, stając się kimś, kim można się posłużyć, kogo można użyć do swoich celów i nad kim można panować. Ciało, które zostało stworzone jako piękne i dobre, przestało być jednoznacznym odzwierciedleniem tajemnicy Boga, Jego obrazu i podobieństwa, wyrażającym jednoznacznie prymat zasady duchowej w człowieku, a stało

17 Por. M. Paradiso, Nell'intimo di Dio. La teologia trinitaria di Hans Urs von Balthasar, Roma 2009, s. 256-262.

18 Tradycja teologiczna wielokrotnie zwracała uwagę na trynitarną genezę stworzenia. Por. np. J. J. O’Donnell, Tajemnica Trójcy Świętej, tł. P. Wilczek, Kraków 1993, s. 179-191. 
się źródłem pokusy, usiłującej sprowadzić je do przedmiotu pożądania. Stało się miejscem, w którym głęboko ukrywa się to, co duchowe, oraz wyraża się podział i napięcie między mężczyzną i kobietą.

\section{Aspekty chrystologiczne}

W jaki sposób Bóg w swojej nieskończonej mądrości przezwycięża tragiczny podział, który naznaczył dramatem egoizmu relacje mężczyzny i kobiety? Aby odpowiedzieć na to pytanie, trzeba sięgnąć do chrystologii. Jak już zostało wspomniane, komunia Boża jest doskonałą komunią dialogiczną. Wspólnota zaś ludzka, powołana do dialogu, stała się z powodu grzechu wspólnotą dialektyczną, której cechą charakterystyczną jest nieustanne napięcie wewnętrzne, uniemożliwiające łatwe przekraczanie siebie w stosunku do drugiego.

Urzeczywistniając zbawczy zamysł Boga bogatego w miłosierdzie, Jezus Chrystus wszedł w świat naznaczony przez grzech, zanurzył się w dialektykę sprzeczności, stał się uczestnikiem dramatu międzyosobowego, nie przerywając dialogu miłości z Ojcem oraz nawiązując nowy dialog z mężczyzną i kobietą. Kluczem do rozumienia tego wydarzenia jest tożsamość Chrystusa jako Syna. Jak już zostało zaznaczone, Jezus jako Syn jest zawsze doskonałą odpowiedzią miłości w stosunku do Ojca. Cały Jego byt polega na Jego „tak” mówionym woli Ojca i w tym „tak” wyraża się w sposób dokonały i osobowy Jego Boska tożsamość. W ten sposób także dla Jezusa Jego osoba zostaje określona przez Jego powołanie. Synostwo Jezusa jest więc istotnie złączone z Jego posłuszeństwem. W Jego wiecznym posłuszeństwie względem Ojca znajduje się podstawa Jego misji, która polega na doprowadzeniu świata do poznania Ojca i Jego miłości, tego świata, który jest naznaczony przez grzech. By to lepiej uchwycić, trzeba zwrócić uwagę na wewnętrzne przenikanie zachodzące między Wcieleniem i krzyżem - obydwie tajemnice są powiązane dogłębnie z kenozą Syna (por. Flp 2, 6-8). Cały byt i całe posłanie Jezusa służy temu, aby stworzyć przestrzeń dla Ojca - by ukazać to miejsce, „gdzie” Jezus jest w Ojcu. Ponieważ On jest zawsze w Ojcu, jest obojętne, czy przeżywa to „gdzie” w łonie Trójcy Świętej czy też na ziemi. W obydwu przypadkach Jego „centrum” jest jednoznacznie określone - jest nim Jego Ojciec. Jego posłuszeństwo względem Ojca jest tak radykalne, że Jezus pozwala się przybić do krzyża i na wieczność nosi już znaki tego przybicia (por. Ap 5, 6). Gdy Jezus umiera, umiera w poczuciu skrajnego opuszczenia przez Boga; nie doświadcza już miłości Ojca, ale tylko Jego czystą wolę. Jezus pozostaje jednak posłuszny, zachowuje do końca wewnętrzny dialog z Ojcem. 


\section{Niektóre konsekwencje w odniesieniu do małżeństwa}

Z tej chrystologii skoncentrowanej na krzyżu i zakorzenionej w Trójcy wynikają liczne i ważne konsekwencje dla chrześcijańskiego rozumienia małżeństwa. W krzyżu Chrystusa widzimy przede wszystkim zrealizowaną konkretnie postać wierności Boga względem człowieka, a tym samym zostaje ukazany właściwy obraz i zasięg wierności mężczyzny i kobiety w małżeństwie. Święty Paweł w Liście do Efezjan $(5,21$-33) pokazał, że właśnie w tym wydarzeniu należy szukać decydującego spojrzenia na małżeństwo. Przez odniesienie do wydarzenia krzyża w jego wewnętrznej nośności zdajemy sobie sprawę, czym jest miłość. Aby tę nośność odkryć, trzeba spojrzeć na niego w perspektywie „eucharystycznej”, którą zapowiada wydarzenie Wieczernika. Spojrzenie zewnętrzne na sam krzyż nie wystarcza, aby zrozumieć jego przesłanie miłości. Wymiar eucharystyczny krzyża wskazuje przede wszystkim na to, że miłość jest ostatecznie wydaniem się za drugiego i innych oraz w tym wydaniu się spełnia. Tak zostaje wydobyty i utrwalony jej wymiar ekstatyczny. Krzyż widziany w perspektywie eucharystycznej jest „ekstazą” miłości Syna względem Ojca, a przez Niego staje się ekstazą miłości względem każdego człowieka. W eucharystycznej perspektywie krzyża zostaje rzucone decydujące światło na ludzką płciowość i jej „język”, który urzeczywistniając wzajemność i komunię mężczyzny i kobiety ma stawać się w coraz właściwszym znaczeniu językiem miłości ${ }^{19}$.

Z płciowością jest więc ściśle złączone oddanie fizyczne, ale takie oddanie, które w najwyższym stopniu ma charakter osobowy, oznaczając właściwie biorąc oddanie drugiemu swojego życia. Ma ono ścisły związek ze słowami Chrystusa wypowiedzianymi w kontekście eucharystycznym: „Nikt nie ma większej miłości od tej, gdy ktoś życie swoje oddaje za przyjaciół swoich” (J 15, 13). Równocześnie samooddanie Jezusa jest darem dawanym aż do śmierci - w miłości aż do końca (por. J. 13, 1). Oddanie Chrystusa na krzyżu wyznacza więc ostateczną perspektywę, w której należy usytuować oddanie fizyczne w małżeństwie.

Na drugim miejscu w śmierci Jezusa na krzyżu zostaje rozwiązywany problem zależności zachodzącej między płciowością i śmiercią. Jezus nie dał nigdy swego ciała drugiemu w małżeństwie; nigdy nie doświadczył zjednoczenia fizycznego z kobietą. On wydał swoje ciało za wielu, jak sam stwierdził w czasie Ostatniej Wieczerzy, ustanawiając Eucharystię - sakrament miłości wydającej się dla innych (por. Mt 26, 28 par.). W tej śmierci należy widzieć niezmierną płodność. Moc odkupieńcza tej śmierci jest tak wielka, że obejmuje wszystkich ludzi - mężczyzn i kobiety. Tutaj wyłania się ścisła linia podziału między Starym i Nowym Testamentem. W Starym Testamencie bezpłodność

19 Por. N. de Martini, Sessualità linguaggio d'amore. La maturità sessuale aspetto della maturità globale, Cinisello Balsamo 1994. 
była przekleństwem - zachodziła konieczność wydania na świat dzieci, ponieważ w przeciwnym wypadku to śmierć wypowiadałaby ostatnie słowo nad losem człowieka ${ }^{20}$. W Starym Testamencie płodność fizyczna zawsze była znakiem nadziei związanym z obietnicą Bożą dotyczącą posłania Mesjasza. Wraz z zawarciem na krzyżu Nowego Przymierza, Bóg ofiaruje ludzkości nową możliwość - dziewictwo ze względu na Królestwo Boże. Po przyjściu Mesjasza płodność fizyczna zostaje zrelatywizowana przez jej otwarcie na płodność duchową. Ponieważ mężczyźni i kobiety są przeznaczeni do życia wiecznego w zmartwychwstaniu, jest możliwe tu i teraz przeżywanie ślubu dziewictwa, to znaczy życie ze względu na płodność duchową, dawanie siebie i swojego ciała nie jedno drugiemu, ale całej wspólnocie w jej pełniejszym urzeczywistnianiu się i w pełnionej przez nią misji ${ }^{21}$.

Równie ważny jest także trzeci wymiar, a mianowicie sakramentalność małżeństwa uwidoczniona i ukonstytuowana w miłości Chrystusa do Jego Kościoła, rozpatrywana w darze siebie złożonym przez Niego na krzyżu. Teologia trynitarna i teologia krzyża łączą się ściśle ze sobą. Zachodzi analogia między trzema obrazami: jak wieczny Syn jest zrodzony z łona Ojca, tak Ewa jest zrodzona z boku Adama, a Kościół jest zrodzony z boku Chrystusa. Te obrazy ukazują, jak jest radykalne, wewnętrzne i dogłębne zjednoczenie, do którego w małżeństwie są powołani mężczyzna i kobieta ${ }^{22}$. Jest ono tak radykalne, jak zjednoczenie osób w Trójcy Świętej. Jest to taka sama miłość, jak ofiarna miłość Chrystusa do Jego Kościoła. Chrześcijańska norma miłości małżeńskiej ma zdecydowane zakorzenienie i kryterium urzeczywistniania się w Jezusie Chrystusie. Mężczyzna powinien kochać swoją żonę tak samo, jak Chrystus ukochał oraz nieustannie i niezmiennie kocha swój Kościól. Gdy mężczyzna oddaje własne ciało swojej żonie we współżyciu płciowym, biologicznie daje swoje nasienie, ale mąż chrześcijański wie, że jego akt wyraża o wiele więcej. Jest on dowodem całkowitego daru z siebie dawanego swojej żonie. Gdy kobieta oddaje się swemu mężowi, jest to dar miłości składany w taki sposób, w jaki Syn zawsze mówi swoje „tak” Ojcu, a zarazem w jaki Kościół wypowiada swoje „tak” Chrystusowi jako swemu Oblubieńcowi. Ponieważ w tym miejscu wszystko posiada wymiar chrystologiczny, nie ma w najmniejszym stopniu miejsca dla mówienia o tym,

20 Por. L. A. Schökel, I nomi dell'amore. Simboli matrimoniali nella Bibbia, Casale Monferrato 1998, s. 193-218.

21 Por. A. Chapelle, Sexualité et Sainteté, Bruxelles 1977, s. 58-129.

22 Warto zwrócić uwagę, że soborowa konstytucja Gaudium et spes, definiując małżeństwo określa je właśnie jako „głęboką (intima) komunię życia i miłości” (nr 48). Ten przymiotnik: głęboka, wewnętrzna, jest często pomijany w interpretacjach tekstu soborowego, a tymczasem należałoby mu nadać bardzo zasadnicze znaczenie w rozpatrywaniu rzeczywistości małżeństwa. 
że ktoś jest „ponad”, a ktoś jest „pod”. Relacja między mężczyzną i kobietą zakłada zróżnicowanie ról i zadań, ale zarazem proklamuje równość miłości i równość w miłości, która sprawia, że drugi jawi się jako absolut.

Pojawia się w tym miejscu zagadnienie płodności. Trzeba przede wszystkim powiedzieć, że każda autentyczna miłość w punkcie wyjścia i w swoim urzeczywistnianiu się jest płodna, czyli - jak dzisiaj chętnie i słusznie się mówi w języku fenomenologicznym - „otwarta na życie”. Ostatecznym argumentem, który to potwierdza, jest jedna i troista miłość Ojca i Syna, która przelewa się w Duchu Świętym. W płodności fizycznej męża i żony, wyrażającej się w dziecku, ukazuje się najwyraźniej płodność miłości. Płodność fizyczna miłości małżeńskiej jest najlepszym obrazem Trójcy, jaki możemy znaleźć pośród ludzkich doświadczeń. Za każdym razem, gdy mąż i żona wyrażają swoją miłość w sposób fizyczny, nie tylko przeżywają oni we wzajemnej relacji rzeczywistość Trójcy Świętej, ale otwierają siebie samych na tę płodność, w której sam Bóg daje im udział. Tę rzeczywistość chce wyrazić klasyczne słowo języka chrześcijańskiego, jakim jest słowo „prokreacja”, i tego słowa musimy bronić w naszym mówieniu o płodności i jej urzeczywistnianiu w małżeństwie, ponieważ najlepiej wyraża ono więź płodności ludzkiej z tajemnicą miłującego Boga Stwórcy. Stosowane dzisiaj $z$ naciskiem słowo „reprodukcja” jest banalizowaniem (zapewne świadomym) tajemnicy osobowej i religijnej, z jaką mamy w tym przypadku do czynienia.

Należy tu ponadto zauważyć, że płodność nigdy nie może być na zimno „kalkulowana”; zawiera ona zawsze element spontaniczności i niespodzianki. Usiłowanie skalkulowania płodności byłoby pozbawianiem jej charakteru osobowego i tajemniczego. Usiłowanie zablokowania płodności miłości małżeńskiej jest zarazem dogłębną sprzecznością w sobie. Małżonkowie mają za zadanie otwierać się w wierze na każdą płodność, jaką Bóg suwerennie dla nich wybierze. Także brak potomstwa ma w sobie coś tajemniczego i wpisuje się w tę logikę płodności Bożej²3. Odrzucenie antykoncepcji wynika z personalistycznego rozumienia małżeństwa, które ma swój wyznacznik w stwierdzeniu Listu do Efezjan, według którego Chrystus wydaje się za swój Kościół jako umiłowaną Oblubienicę (rozdz. 5). Stosowane powszechnie w teologii odwoływanie się do prawa naturalnego, aby odrzucić antykoncepcję i wykazać jej grzeszność24, wydaje się nie być konieczne, gdy rozpatrujemy małżeństwo w perspektywie

$23 \quad$ Papież Franciszek w adhortacji Amoris laetitia przywołał trafną wypowiedź św. Roberta Bellarmina: „Fakt, że jeden mężczyzna i jedna kobieta łączą się węzłem wyłącznym i nierozerwalnym, tak że nie mogą się oddzielić, bez względu na trudności, nawet jeśli stracono nadzieję na potomstwo, nie może się zdarzyć bez wielkiej tajemnicy" (nr 124).

24 Por. np. K. Krajewski, Moralne zło antykoncepcji, [w:] Dar ciała darem osoby. O przemilczanym wymiarze kryzysu więzi matżeńskiej, P. Ślęczka (red.), Lublin 2005, s. 31-38. 
teologiczno-chrystologicznej, która stanowi najwyższe objawienie osoby i tajemnicy miłości, w tym także miłości płodnej.

$* * *$

Teologia trynitarna i chrystologia dostarczają bogatego materiału do pogłębionego rozumienia i dowartościowania nauczania ostatnich papieży, którzy zwracają konsekwentnie uwagę na potrzebę usytuowania podstawowych zagadnień dotyczących powołania, natury i misji małżeństwa w ścisłym odniesieniu do tajemnicy Trójcy Świętej i tajemnicy Jezusa Chrystusa. Perspektywy teologiczne, respektując jednoznacznie wnioski wypływające $z$ teologii stworzenia i z prawa naturalnego, otwierają wyjątkowo szeroką perspektywę do spojrzenia na małżeństwo, będące podstawową rzeczywistością ludzką i chrześcijańską, jako na „wielką tajemnicę”, która ma swoją genezę w najwyższej tajemnicy Boga Trójcy i zostaje w pełni objawiona w Jezusie Chrystusie, Wcielonym Synu Bożym, który umarł na krzyżu w kenozie miłości. Jest to więc przede wszystkim perspektywa personalizmu zakorzenionego i ukierunkowanego chrystologicznie. Wzajemne oddanie się małżonków sobie w małżeństwie jest wyjątkowym świadectwem dawanym Chrystusowi, ponieważ wierność wyrażana w obrazach małżeńskich odzwierciedla radykalizm i wielkość miłości poświadczonej raz na zawsze w krzyżu Chrystusa. Płodność ich zjednoczenia fizycznego odzwierciedla nie tylko niezmierzoną płodność Jego śmierci za ludzkość, ale także nieskończoną płodność komunii trynitarnej, która rozlewa się na każdą rzeczywistość stworzoną i staje się jej pierwotnym punktem odniesienia.

Słowa kluczowe: Trójca Święta, Jezus Chrystus, miłość, małżeństwo, płodność.

\section{Bibliografia:}

1. Carlotti P., La famiglia comunione di persone. Alcune considerazioni sulla Lettera alle Famiglie di Giovanni Paolo II, „Salesianum” 56 (1994) s. 717-740.

2. Chapelle A., Sexualité et Sainteté, Bruxelles 1977.

3. Gendron L., Le mystère de la Trinité et la simbolique familiale, Roma 1975.

4. Grygiel S., Errantes revoca! Esej o samoświadomości, Transcendencji i pojednaniu, [w:] Teksty filozoficzne, Kraków 1986, s. 142-160.

5. Hildebrandt D. von, Die Ehe, München 1929.

6. Krajewski K., Moralne zło antykoncepcji, [w:] Dar ciała darem osoby. O przemilczanym wymiarze kryzysu więzi matżeńskiej, P. Ślęczka (red.), Lublin 2005, s. 31-38.

7. Mader J., Filozofia dialogu, [w:] Teksty filozoficzne, Kraków 1985, s. 59-86.

8. Margerie B. de, La Trinité chrétienne dans l'histoire, Paris 1975.

9. Maritain J., Pisma filozoficzne, tł. J. Fenrychowa, Kraków 1988. 
10. Maritain J., Maritain R., Matrimonio, amore e amicizia. Per una spiritualità della vita coniugale, Milano 1994.

11. Martini N. de, Sessualità linguaggio d'amore. La maturità sessuale aspetto della maturità globale, Cinisello Balsamo 1994.

12. Od wiary do teologii. Dokumenty Międzynarodowej Komisji Teologicznej 1969-1996, J. Królikowski (red.), Kraków 2000.

13. O’Donneli J. J., Tajemnica Trójcy Świętej, tł. P. Wilczek, Kraków 1993.

14. Ouellet M., Divina somiglianza. Antropologia trinitaria della famiglia, t. 1, Roma 2004.

15. Paradiso M., Nell'intimo di Dio. La teologia trinitaria di Hans Urs von Balthasar, Roma 2009.

16. Scheeben M. J., Tajemnice chrześcijaństwa, tł. J. Rostworowski, I. Bieda, Kraków 1970.

17. Scheeben M. J., Handbuch der katcholischen Dogmatik, Freiburg im Br. 1933.

18. Schökel L. A., I nomi dell'amore. Simboli matrimoniali nella Bibbia, Casale Monferrato 1998.

19. Scola A., Il mistero nuziale. Studi sulla persona e la famiglia, t. 1-2, Milano 1998-2000.

20. Sołowjow W., Sens mitości, tł. H. Paprocki, Kęty 2002.

21. Teilhard de Chardin P., O szczęściu, cierpieniu, mitości, tł. W. Sukiennicka, M. Tazbir, Warszawa 2001. 